\title{
The impact of $\beta$-hCG on placental angiogenesis in pre-eclampsia
}

\author{
Sri Bekti Subakir, Tri Jauhari", Pramita Iriana ${ }^{\S}$, Minarma Siagian*, Sutarmo Setiadji
}

\begin{abstract}
Abstrak
Banyak faktor yang mempengaruhi aktivitas angiogenesis plasenta, misalnya VEGF dan oksigenasi dalam plasenta. Pada awal kehamilan normal $\beta$-hCG meningkatkan aktivitas VEGF untuk merangsang angiogenesis. Tujuan penelitian ini adalah untuk mengetahui hubungan antara kadar $\beta$-hCG pada kultur plasenta dengan aktivitas angiogenik plasenta preeklampsia. Sampel plasenta diambil dari 10 plasenta wanita dengan preeklampsia dan 10 kontrol (wanita dengan kehamilan normal). Semua subjek bersedia berpartisipasi dalam penelitian ini dan menandatangani informed consent. Konsentrasi $\beta$-hCG dalam supernatan kultur plasenta diukur dengan Microparticle Enzyme Immunoassay (MEIA) dan aktivitas angiogenik plasenta diukur dengan mengukur migrasi sel endotel menuju eksplan plasenta (skor 0-4). Hasil menunjukkan median skor aktivitas angiogenik plasenta pada preeklampsia lebih tinggi secara bermakna dari kontrol $(p<0,05)$. Konsentrasi $\beta$-hCG dalam kultur plasenta preeklampsia lebih tinggi secara bermakna dari plasenta kehamilan normal ( $p<0,001)$. Konsentrasi $\beta$-hCG mempunyai korelasi positif dengan aktivitas angiogenik plasenta baik pada preeklampsia $(r=0,50)$ maupun kehamilan normal $(r=0,57)$. Walaupun korelasi ini lemah, bagaimanapun juga $\beta$-hCG merupakan salah satu faktor yang mempengaruhi aktivitas angiogenik plasenta. (Med J Indones 2005; 14: 67-70)
\end{abstract}

\begin{abstract}
Numerous factors, such as VEGF and intra-placental oxygenation, can influence placental angiogenic activity. Early in the normal gestation period, $\beta$-hCG enhance VEGF activity to induce angiogenesis. The aims of this study were to identify the correlation between $\beta$-hCG concentration in placental culture and placental angiogenic activity in pre-eclampsia. Ten placenta samples from women with pre-eclampsia and 10 from controls (normal pregnancy) were collected. All subjects agreed to participate in this study and signed an informed consent form. $\beta$-hCG concentration in supernatant of placental culture was measured by Microparticle Enzyme Immunoassay (MEIA) and placental angiogenic activity was measured by endothelial cell migration toward placental explant (score 0-4). The results showed that the median score of placental angiogenic activity in pre-eclampsia was significantly higher than in normal pregnancy $(p<0.05)$. Concentration of $\beta-h C G$ in pre-eclampsia was significantly higher than in normal pregnancy $(p<0.001)$. hCG concentration in placental culture was positively correlated to placental angiogenic activity both in pre-eclampsia $(r=+0.50)$ and in normal pregnancy $(r=+0.57)$. Although the correlations were weak, $\beta$-hCG is considered one of the factors that influence placental angiogenic activity. (Med J Indones 2005; 14: 67-70)
\end{abstract}

Keywords: angiogenesis, $\beta$-hCG, placenta, pre-eclampsia

Angiogenesis is the generation of new blood vessels from pre-existing blood vessels. The rate of placental blood flow is dependent on placental vascularization and placental angiogenesis. Placental angiogenesis can be classified as branching and non-branching angiogenesis. In normal pregnancy branching angiogenesis

\footnotetext{
* Department of Physiology, Faculty of Medicine, University of Indonesia, Jakarta, Indonesia

\# Department of Physiology, Faculty of Medicine, Sudirman University, Purwokerto, Indonesia

$\S$ Academy of Nursing, Polytechnic of Health, Department of Health, Jakarta III, Indonesia
}

occurs predominantly in the first and second trimester, while non branching angiogenesis occurs in the third trimester. Numerous factors influence placental angiogenic activity, such as vascular endothelial growth factor (VEGF), placental growth factor (PIGF), and placental oxygenation. ${ }^{1,2}$

It is believed that the placenta is central to the etiology of pre-eclampsia. If the uterine blood vessels do not develop adequate vascular transformation, uterine blood flow is then reduced and placental oxygenation falls. This hypoxia induces VEGF secretion. VEGF is a potent endothelial cell (EC) mitogen. VEGF induces migration and proliferation of $\mathrm{EC}$, 
causing increased vascular permeability. VEGF also promotes EC survival by inhibiting apoptosis. ${ }^{3,4}$ In early pregnancy, VEGF secretion is enhanced by the human chorionic gonadotropin (hCG) hormone. ${ }^{5}$

Patients with overt pre-eclampsia have increased maternal serum hCG levels in the third trimester. The placenta is the main source of hCG in patients with pre-eclampsia. It is suggested that hCG secretion may be increased as a consequence of abnormal placentation or placental immaturity. ${ }^{6}$ Increased vascular resistance in fetoplacental circulation is characteristic of preeclampsia. ${ }^{7}$ As a response, angiogenic activity will be increased and enhance blood flow in placental microcirculation. Does the hCG concentration in the placenta induce placental angiogenic activity in preeclampsia? It is suggested that hCG induces angiogenic activity via enhances VEGF secretion.

\section{METHODS}

\section{Subject}

Subjects were selected from Budi Kemuliaan Maternity Hospital. Women with normal pregnancy (10) and with pre-eclampsia (10) were enrolled in this study after they signed an informed consent form. The gestation ranged from 21-40 weeks. Placenta samples were collected immediately after delivery, which was either normal or by cesarean section, and placed in a sterile container filled with RPMI 1640 solution (Flow Laboratories, USA). The sample was then transported to the laboratory within 1 hour.

Upon arrival, the placenta sample was washed with phosphate buffer saline (PBS) and betadine. The connective tissue was discarded. The sample was cultured in conical tubes. ${ }^{8}$ Approximately 5 gram of cotyledon was minced finely and teased with PBS, and then centrifuged at $1000 \mathrm{~g}$ for 3 minutes. The pellet produced was re-suspended by PBS and then 2 $\mathrm{ml}$ Trypsin $0.025 \%$ was added. The tube was put into the incubator for 5 minutes, and then $1 \mathrm{ml}$ fetal bovine serum (FBS, Sigma, USA) added. It was recentrifuged at $1000 \mathrm{~g}$ for 3 minutes. The pellet was again re-suspended with $3 \mathrm{ml}$ PBS and the remaining red blood cell was lysed using $3 \mathrm{ml}$ hypotonic solution $\left(8.29 \mathrm{~g} \mathrm{NH}_{4} \mathrm{Cl}, 1.0 \mathrm{~g} \mathrm{NaHCO}_{2}\right.$ and $0.0371 \mathrm{~g}$ EDTA in 1 liter $\mathrm{H}_{2} \mathrm{O}$ ). The tube again put into incubator for 10 minutes and then re-centrifuged again at $1000 \mathrm{~g}$ for 3 minutes. The pellet was re-suspended with $3 \mathrm{ml}$ RPMI 1640, FBS 20\%, gentamycin, and Fungizone (Flow Laboratories). Finally, the suspension was incubated at $37^{\circ} \mathrm{C}$ and $5 \% \mathrm{CO}_{2}$. After 3 days, the supernatant were collected for $\beta$-hCG assay.

\section{$\beta$-hCG assay}

The $\beta$-hCG concentration in the supernatant of the placental culture was measured with the AxSYM Total $\beta$-hCG kit (Abbot, USA). The supernatant was diluted 1:10, because the concentration of $\beta$-hCG was predicted to be more than $1000 \mathrm{mIU} / \mathrm{ml}$. The principle of this assay is an antigen-antibody reaction. The $\beta$ hCG binds to both the enzyme-labeled antibody and the antibody-coated microparticle forming an antibody-antigen-antibody complex. An aliquot of this complex was transferred to the matrix cell and the microparticles bound irreversibly to the fiber of the glass matrix. Addition of 4-methylumbeliferyl phosphate to the matrix cell will lead to production of a fluorescent product. This product was then measured with the Microparticle Enzyme Immunoassay (MEIA) optical assembly.

\section{Angiogenesis assay}

Placental angiogenic response was measured based on the migration of endothelial cells toward the placental explants in a three-dimensional collagen matrix culture medium. ${ }^{9}$ In this study $10^{4}$ endothelial cell line (Vero) was suspended in $2 \mathrm{ml} \mathrm{NCTC} \mathrm{(Flow} \mathrm{Laboratories),} \mathrm{20 \%}$ FBS, gentamycin and fungizone. The medium was adjusted by $0.4 \mathrm{ml}$ of $0.1 \mathrm{~N} \mathrm{NaOH}$ to reach a $\mathrm{pH}$ of 7.6 after addition of $2 \mathrm{ml}$ chilled vitrogen 100 (Collagen Corporation, Palo Alto, USA). One $\mathrm{ml}$ of the matrix solution was placed to each of the 4 wells in the culture plate (Nunc, Finland). Three or four placental explants measuring $500 \mu \mathrm{m}$ were placed in three wells. The fourth well was used for a control blank.

The culture plate was incubated at $37^{\circ} \mathrm{C}$ and $5 \% \mathrm{CO}_{2}$ for $96 \mathrm{~h}$ and observed at $24 \mathrm{~h}$ intervals using inverted phase-contrast microscope. The angiogenic score ranged from 0 to 4 . Score $0=$ no endothelial cell response, $1=$ elongation and some orientation towards explant, $2=$ minimal spoke-wheel response, $3=$ medium spoke-wheel response and $4=$ extreme spoke-wheel formation. 


\section{Statistical analysis}

Mean $\beta$-hCG was calculated and the differences between the two groups were analysed using the student's t test. The placental angiogenic score for each placenta was the median response for each placental explant. Differences in placental angiogenic scores between the two groups were analyzed using the Mann-Whitney test. The relationship between $\beta$ hCG concentration and angiogenic score were analyzed using the Spearman's rank correlation. ${ }^{10}$

\section{RESULTS}

There was no difference in the length of gestation (in weeks) between women with preeclampsia and normal pregnancy $(38.8 \pm 1.55$ weeks versus $37.4 \pm 3.80$ weeks, $\mathrm{p}<0.05)$. The concentration of $\beta-\mathrm{hCG}$ was significantly higher in the preeclamptic placenta than in normal pregnancy $(3121.5 \pm 2398.8 \mathrm{mIU} / \mathrm{ml}$ versus $653.2 \pm 643.4 \mathrm{mIU} / \mathrm{ml}, \mathrm{p}<0.001)$. Placental angiogenic activity was significantly higher in preeclampsia than in normal pregnancy $(p<0.05)$. There was a positive correlation between the concentration of $\beta$-hCG and the median score of placental angiogenic response both in normal pregnancy $(\mathrm{r}=0.57)$ and in preeclampsia $(r=0.50)$.

\section{DISCUSSION}

This study showed that placental angiogenic response is significantly higher in women with preeclampsia than the control group. In pre-eclampsia, a reduction of villous oxygen content occurs at term. The placenta adapts to this situation by increasing the highly vascularized terminal villi, which leads to enhanced intra-placental oxygen concentration. ${ }^{2}$

There is a general agreement that the placenta remains the main source of $\mathrm{hCG}$ in pre-eclampsia. The increased secretion of hCG is a consequence of abnormal placental immaturity. ${ }^{6}$ It is suggested that the hCG-mediated effects of VEGF induce increase vascularization or angiogenic activity. ${ }^{6}$ In this study, the VEGF was not measured, but a recent study showed that VEGF sera in women with pre-eclampsia is slightly increased. ${ }^{11}$ Secretion of hCG also increased in vitro capillary formation and migration of endothelial cells. ${ }^{12}$ It is suggested that hCG tends to enhance placental angiogenic activity in preeclampsia.

\section{CONCLUSION}

The placental angiogenic response and the concentration of $\beta$-hCG were significantly higher in women with preeclampsia than the control group. Although the correlation between hCG concentration and angiogenic activity was weak however hCG is still considered one of the many factors which play a role in inducing placental angiogenic activity in pre-eclampsia.

\section{Acknowledgments}

This study was funded by Hibah Tim Pascasarjana, DPRM, and DIKTI.

Tabel 1. Week of gestation, $\beta$-hCG concentration, and median score of placental angiogenic response in women with preeclampsia and normal pregnancy

\begin{tabular}{cccccccc}
\hline & \multicolumn{3}{c}{ Normal pregnancy } & & \multicolumn{3}{c}{ Preeclampsia } \\
\hline No. & $\begin{array}{c}\text { Week of } \\
\text { gestation }\end{array}$ & $\begin{array}{c}\beta \text {-hCG } \\
(\mathrm{mIU} / \mathrm{ml})\end{array}$ & $\begin{array}{c}\text { Angiogenic } \\
\text { score }\end{array}$ & No. & $\begin{array}{c}\text { Week of } \\
\text { gestation }\end{array}$ & $\begin{array}{c}\beta \text {-hCG } \\
\text { (mIU/ml) }\end{array}$ & $\begin{array}{c}\text { Angiogenic } \\
\text { score }\end{array}$ \\
\hline N1 & 40 & 167.1 & 0 & P1 & 40 & 1100 & 0 \\
N2 & 40 & 297.6 & 0 & P2 & 40 & 2069.9 & 0 \\
N3 & 40 & 406.3 & 0 & P3 & 40 & 4113.6 & 0 \\
N4 & 40 & 410.0 & 0 & P4 & 40 & 2049 & 1 \\
N5 & 40 & 634,4 & 0 & P5 & 39 & 721.1 & 0 \\
N6 & 40 & 753,1 & 0 & P6 & 39 & 2888 & 1 \\
N7 & 36 & 151.5 & 0 & P7 & 39 & 8365 & 1 \\
N8 & 35 & 487,7 & 0 & P8 & 38 & 651.1 & 1 \\
N9 & 34 & 2356,9 & 0 & P9 & 38 & 5130.2 & 1 \\
N10 & 29 & 894 & 1.0 & P10 & 35 & 4127.5 & 1 \\
\hline
\end{tabular}




\section{REFERENCES}

1. Reynolds PL, Redmer DA. Angiogenesis in the placenta. Biol Reprod 2001; 64: 1033-40.

2. Ong S, Lash G, Baker PN. Angiogenesis and placental growth in normal and compromised pregnancies. Balliere's Clin Obstet Gynaecol 2000; 14 (6): 969-80.

3. Chavakis E, Dimmeler S. Regulation of endothelial cell survival and apoptosis during angiogenesis. Arteriscler Thromb Vasc Biol. 2002; 22: 887-93.

4. Page NM. The endocrinology of pre-eclampsia. Clin Endocrinol. 2002; 57: 413-23.

5. Neulen J, Rasczek S, Pogorzelski M, Grunwald K, Yeo TK et al. Secretion of endothelial growth factor/vascular permeability factor from human luteinized granulosa cells is human chorionic gonadotrophin dependent. Mol Hum Reprod. 1998; 4(3): 203-06.

6. Reis FM, d'Antona D, Petraglia F. Predictive value of hormone measurements in maternal and fetal complications of pregnancy. Endocrine Rev. 2002; 23(2): 23057.
7. Lyall F, Greer IA. The vascular endothelium in normal pregnancy and pre-eclampsia. Rev Reprod. 1996; 1:107-16.

8. Rand JH, Wu X-X, Guiler S, Scher J, Andree HAM et al. Antiphospholipid immunoglobulin $\mathrm{G}$ antibodies reduce annexin- $\mathrm{V}$ levels on syncytiotropoblast apical membranes and in culture media of placental villi. Am J Obstet Gynecol 1997(177): 918-23.

9. Folkman J, Watson K, Ingber D, Hanahan D. Induction of angiogenesis during the transition from hyperplasia to neoplasia. Nature 1989; 239: 58-61.

10. Daly LE, Bourke GJ, McGilvray J (editors) Interpretation and uses of medical statistics, $4^{\text {th }}$ ed London: Blackwell Scientific; 1985; 157-178.

11. Subakir SB, Paramita N, Wardhani I, Wiria MS, Soeradi O. Does VEGF concentration in preeclamptic serum induce sVCAM-1 production in endothelial cell culture? Med J Indones 2004; 14: 3-6.

12. Zygmunt M, Herr F, Keller-Schoenwetter S, Kunzi-Rapp $\mathrm{K}$, Munstedt $\mathrm{K}$ et al. Characterization of human chorionic gonadotropin as a novel angiogenic factor. J Clin Endocrinol Metab 2002; 87(11): 5290-96. 